\title{
Redescription of Dysdera cylindrica (Aranei: Dysderidae) from Pakistan with notes on the distribution of the family
}

\author{
Переописание Dysdera cylindrica (Aranei: Dysderidae) из \\ Пакистана и заметки по распространению семейства
}

\author{
Yuri M. Marusik \\ Ю.М. Марусик
}

\footnotetext{
${ }^{1}$ Institute for Biological Problems of the North RAS, Portovaya Str. 18, Magadan, 685000 Russia. E-mail: yurmar@mail.ru

${ }^{2}$ Zoology \& Entomology, University of the Free State, Bloemfontein 9300, South Africa.

${ }^{3}$ Zoological Museum, Biodiversity Unit, FI-20014 University of Turku, Finland.

${ }^{1}$ Институт биологических проблем Севера ДВО РАН, Портовая 18, Магадан 685000.
}

KEY WORDS: Araneae, spider, Palaearctic, Oriental region, distribution limits.

КЛЮЧЕВЫЕ СЛОВА: Araneae, паук, Палеарктика, Ориентальная область, границы распространения.

ABSTRACT. Dysdera cylindrica O. Pickard-Cambridge, 1885 is redescribed based on the lectotype male (designated here) and paralectotype female. The species was collected in northern Punjab, Pakistan, but not in Kashmir as indicated in the World Spider Catalog [2017]. Dysdera cylindrica together with D. arnoldii Charitonov, 1956 and D. subcylindrica Charitonov, 1956 form comprise the cylindrica species group. Dysderidae is a single family of spiders endemic to Palaearctic. The family ranges from Azores to Kyrgyzstan. Only six species, all from the genus Dysdera, are known outside the Palaearctic. Five of them are known exclusively from mountains adjacent to the Palaearctic. One species, D. crocata C.L. Koch, 1838 is cosmopolitan due to anthropogenic reasons.

How to cite this article: Marusik Yu.M. 2017. Redescription of Dysdera cylindrica (Aranei: Dysderidae) from Pakistan with notes on the distribution of the family // Arthropoda Selecta. Vol.26. No.4. P.310 314. doi: 10.15298/arthsel.26.4.05

РЕЗЮМЕ. Приводится переописание Dysdera cylindrica O. Pickard-Cambridge, 1885 на основе лектотипа самца (выделен нами) и паралектотипа самки. Вид собран на севере пакистанской провинции Пенджаб, а не в Кашмире, как указано в World Spider Catalog [2017]. Dysdera cylindrica вместе с D. arnoldii Charitonov, 1956 и D. subcylindrica Charitonov, 1956 образуют отдельную группу видов cylindrica. Dysderidae единственное эндемичное ceмейство пауков в Палеарктике. Оно распространено от Азорских островов до Киргизии. Только 6 видов, все из рода Dysdera, известны за пределами Палеарктики. Пять из них встречаются в горах прилегающих к Палеарктике. Один вид, D. crocata C.L.
Koch, 1838 имеет всесветный ареал из за антропогенного расселения.

\section{Introduction}

The spider family Dysderidae has 542 species assigned to 24 genera [WSC, 2017]. Almost half of the species (256) belong to Dysdera Latreille, 1804. Most Dysdera occur in the Mediterranean and the Caucasus [WSC, 2017]. According to the World Spider Catalog [2017] no dysderids are distributed in Pakistan, and only one, Dysdera cylindrica O. Pickard-Cambridge, 1885, is listed as occurring in Kashmir, a geographical region lying both in Pakistan and India. While examining types described by O. Pickard-Cambridge in 1885 , I noticed that $D$. cylindrica was actually described from Murree, a town in Northeastern Punjab, Pakistan. While close to Kashmir, it is located in different state. Having the types on the hand, I decided to redescribe the species and discuss the distribution limits of Dysderidae, which is unusual compared to other spider families.

\section{Material and methods}

Specimens were photographed with a Canon EOS 7D camera attached to an Olympus SZX16 stereomicroscope at the Zoological Museum, University of Turku, Finland. Digital images were montaged using CombineZP image stacking software.

Abbreviations used in the text: AME - anterior median eyes, fe - femur, pa - patella, ti - tibia, $\mathrm{mt}$ - metatarsus, ta - tarsus. Measurements are given in millimetres. The map was taken from the site "https:// maps-for-free.com/"'. 

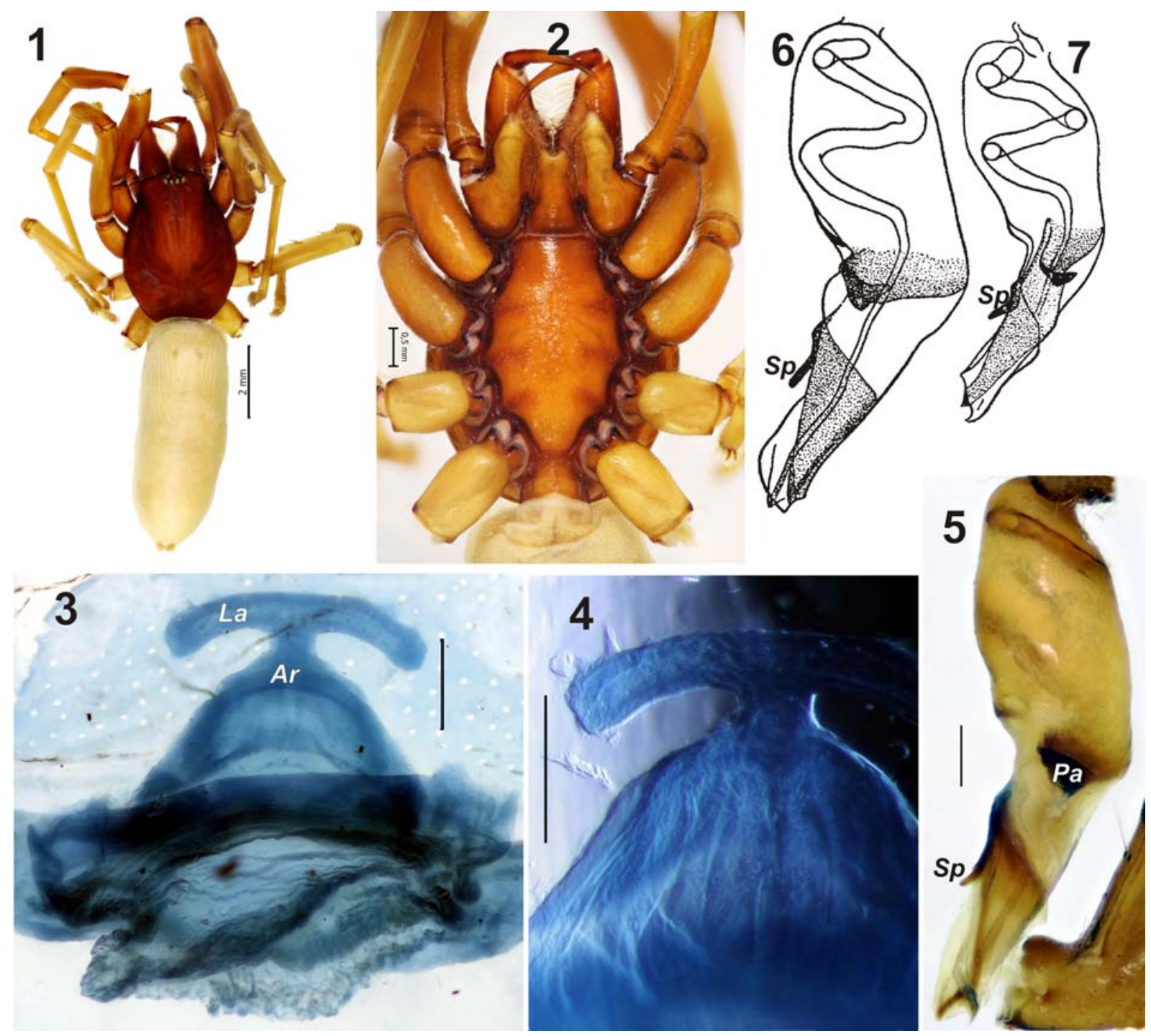

Figs. 1-7. Habitus and copulatory organs of Dysdera cylindrica (1-5), D. subcylindrica (6) and D. arnoldii (7). 1 - male habitus, dorsal; 2 - male prosoma, ventral; 3-4 - endogyne, dorsal, different magnification; 5-7 - male palp, ventral. 6-7 - after Charitonov [1956].

Рис. 1-7. Габитус и копулятивные органы Dysdera cylindrica (1-5), D. subcylindrica (6) и D. arnoldii (7). 1 — габитус самца, сверху; 2 - головогрудь самца, снизу; 3-4 - эндогина, сверху, разные увеличения; 5-7 - пальпы самца, снизу. 6-7 - по Харитонову [1956].

\section{Taxonomy}

Dysdera cylindrica O. Pickard-Cambridge, 1885 Figs 1-5, 8-12. $\left(0^{\top}+\right)$.

Dysdera cylindrica O. Pickard-Cambridge, 1885: 5, pl. 1, f. 3

Dysdera cylindrica: Deeleman-Reinhold \& Deeleman, 1988: 220, f. 247a-d (OT+P).

TYPES: Lectotype $\sigma^{\top}$ (designated here) and paralectotype + in the vial with 2 labels "b[ottle] 378, v[ial] 23, 2 sp[ecimens]" and "16". Text information: "Murree, between June 11th and July 14th, $1873 "$

DIAGNOSIS: The diamond-shaped carapace (especially in the male), the cylindrical, elongated abdomen and the relatively long legs (femur I longer than carapace) distinguish this species from $D$. arnoldii Charitonov, 1956 and D. subcylindrica Charitonov, 1956 (both known from eastern Uzbekistan, Kazakhstan, Kyrgyzstan and Tajikistan). Dysdera cylindrica differs from both species in size: the carapace length of the male is 4.4 , vs. 4.7 in D. subcylindrica, and 3.5 in D. arnoldii. The three species also differ also by eye pattern: the ratio of the distance between the AME to the diameter of eye is $12 / 15$ in D. cylindrica, $8 / 11$ in $D$. arnoldii and 17/14 in D. subcylindrica. Males of the three species well differ by the proportions of the bulb (cf. Figs 5-7) and shape of the terminal part of the bulb. Females of $D$. cylindrica differ from $D$. arnoldii by having a distinct neck of the anterior receptacle (lacking in $D$. arnoldii) and relatively longer lateral 

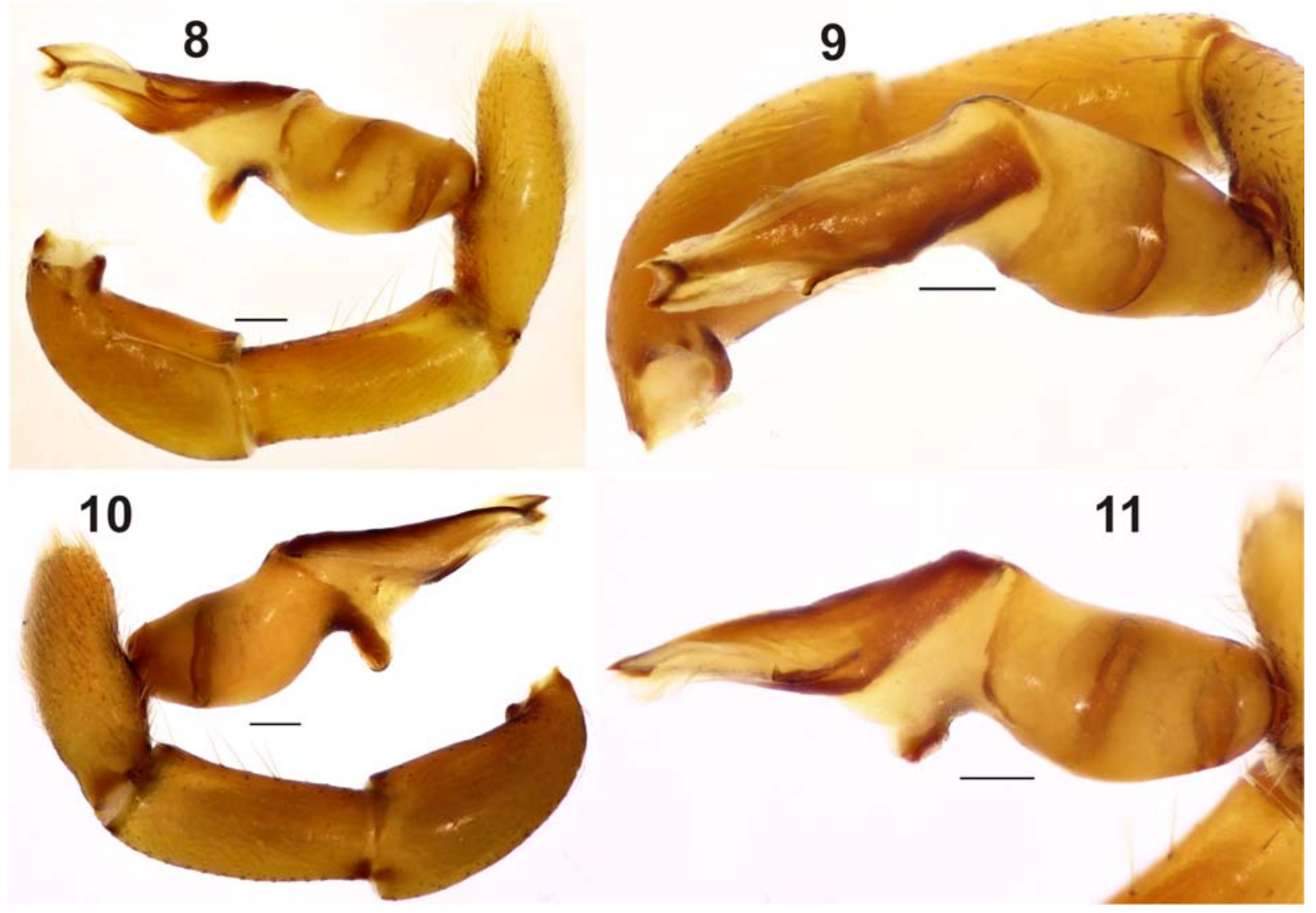

Figs. 8-11. Male palp of Dysdera cylindrica. 8, 10 - retro- and prolateral; 9 - anterior; 11 - dorso-retrolateral. Scale $=0.2 \mathrm{~mm}$.

Рис. 8-11. Пальпа самца Dysdera cylindrica. 8, 10 - ретро- и пролатерально; 9 - спереди; 11 - дорзально-ретролатерально. Масштаб 0,2 мм.

arms of the anterior receptacle (cf. Figs 3-4 and fig. 262 in Deeleman-Reinhold \& Deeleman [1988]). The endogyne of $D$. subcylindrica remains unknown.

DESCRIPTION. Male. Carapace 4.4 long, 3.3 wide, abdomen 6.7 long (Fig. 1). Distance between AME less than AME diameter (ratio 12/15). Chelicera with 3 prolateral teeth. Leg I 15.7 (4.6, 2.5, 4.0, 3.8, 0.8), fe IV 3.9. Spination of leg IV: fe 2 dorso-basal, ti $2 \mathrm{p}, 2 \mathrm{r}$, 5-3v; mt 3p 2r, 6v.

Palp as in Figs 5, 8-11. Length/width ratio ca. 3.3. Posterior apophysis $(\mathrm{Pa})$ trianglular in ventral view (Fig 5), mesal part of embolic portion with elongate sclerotized process $(S p)$ with small hook on the tip (Fig. 8)

Female. Carapace 4.6 long, 3.2 wide, abdomen 8.5 long. General appearance as in male.

Leg I 15.1 (4.4, 2.4, 4.0, 3.5, 0.8); fe IV 4.0.

Endogyne as in Figs 3-4. Anterior "receptacle" (Ar) wide, 7.5 times wider than long, lateral arms $(L a)$ inclined posteriorly; arms with small anterior outgrowths terminally; neck of anterior "receptacle" well developed and visible, as height of the arm.

RELATIONSHIPS. Dysdera cylindrica is rather similar to two species that occur in Central Asia, D. subcylindrica and D. arnoldii, and these three species form a separate species group, cylindrica. All three species have similar bulb proportions (tegular and embolic parts equal in length), a triangular posterior apophysis and small process ( $S p)$ anteriorly (cf. Figs 5-7).

DISTRIBUTION. This species is known only from the type locality, Murree.. Deeleman-Reinhold \& Deeleman [1988] indicated that this species was described from "Asia Centrale Cachemire, Murree, ... 11-14.vii. 1873", although O. Pickard-Cambridge [1885] wrote that this species was collected in Murree (always belonging to the Punjab State) between June 11 and July 14 1873. Ferdinand Stolizka started his trip to Yarkand at July 15 [Blanford, 1879], so the species can not be collected in Kashmir.

\section{Discussion}

Dysderidae is the only family of spiders that is nearly endemic to the Palaearctic and particularly to the Western Palaearctic. Of 542 extant species known in the family, only one, Dysdera crocata C.L. Koch, 1838, has a nearly cosmopolitan distribution due to anthropogenic dispersal. Two species known from females only from the Neotropical region, D. solers Walckenaer, 1837 and D. bicolor Taczanowski, 1874, are seemingly misplaced in the family [WSC, 2017]. The World Spider Catalog [2017] lists only four true dys- 


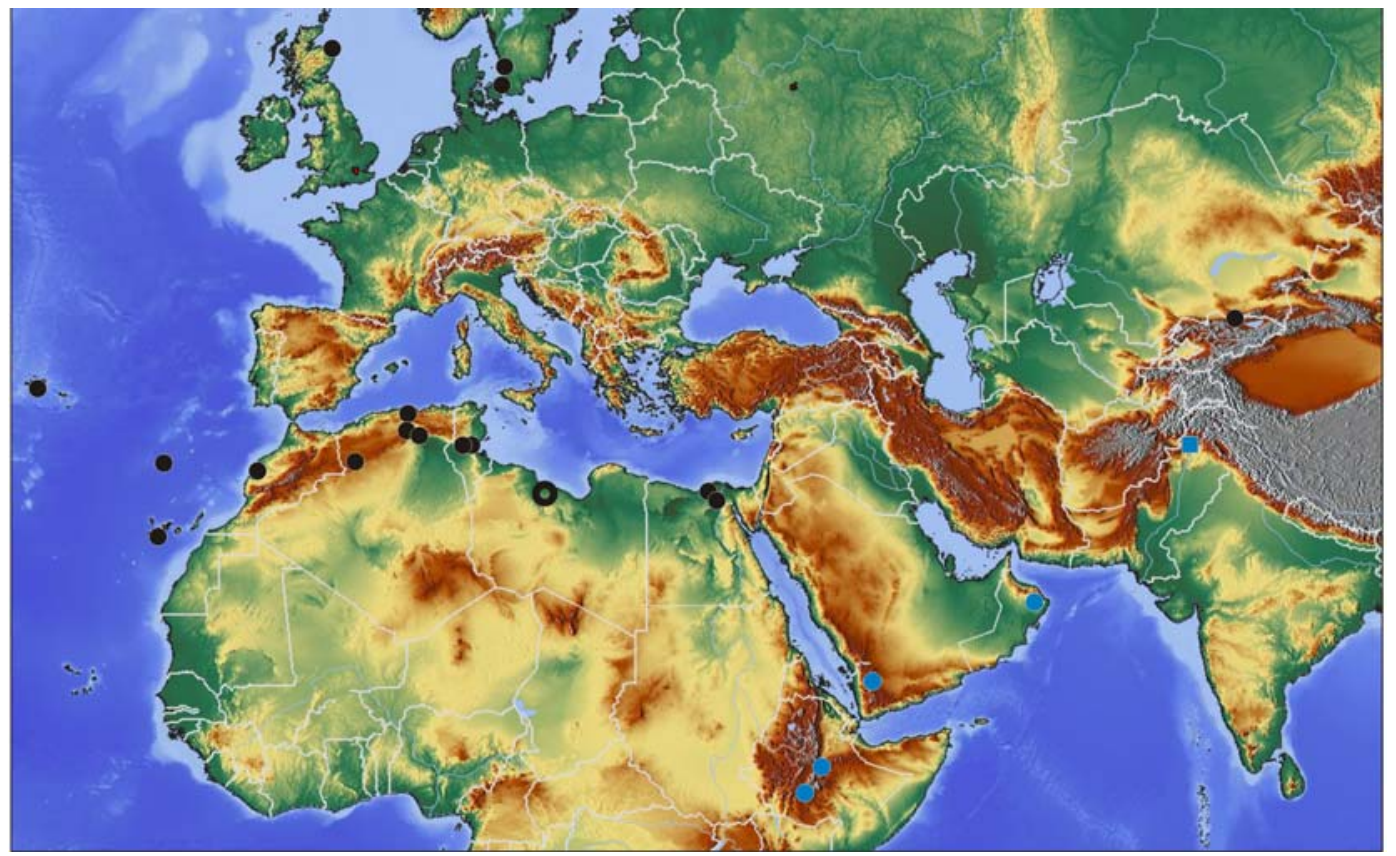

Fig. 12. Distributional limits of Dysderidae showing westernmost, northernmost, southernmost and easternmost localities. The square refers to the type locality of Dysdera cylindrica, black dots to records of the family from the Palaearctic, blue dots refer to species known outside the Palaearctic, and the open circle refers to an unspecified record from Libya.

Рис. 12. Границы распространения семейства Dysderidae: показаны крайние точки распространения. Квадрат - Dysdera cylindrica, залитые кружки - находки Палеарктике; голубые точки - находки за пределами Палеарктики; незалитый кружок находка в Ливии без точной привязки.

derid species occurring outside the Palaearctic, and all of them belong to Dysdera. Two were found in neighboring regions of the Arabian Peninsula, Dysdera arabiafelix Gasparo et van Harten, 2006 (Yemen) and $D$. arabica Deeleman-Reinhold, 1988 (Oman). Two other species, D. dysderoides (Caporiacco, 1947) and D. roemeri Strand, 1906 are known from the highlands of Ethiopia. Other than these four species, D. cylindrica also occurs outside the Palaearctic, but close to the border of the Palaearctic region. All species reported from outside the Palaearctic are restricted to mountains (Fig. 12).

The family is currently distributed from the Canary Islands to Kyrgyzstan (Fig. 12), south to southern part of the Arabian Peninsula, Ethiopia and northern Punjab.

The northern limits of the distribution lie in Scotland. Two species are known from there, Dysdera crocata and Harpactea holmbergi (Scopoli, 1763) [Harvey et al., 2002].

There are also two fossil genera, Dasumiana Wunderlich, 2004 (3 species) and monotypic Segistriites Straus, 1967 (Willershausen amber) and two recent genera Dysdera (1 species) and Harpactea (4 species) [Dunlop et al., 2017]. All fossil species are described from amber inclusions found in Europe except one, Dysdera dilatata Zhang, Sun et Zhang, 1994, from Eastern China which was described based on an impression and is obviously misplaced judging from the figure.

\section{Acknowledgments}

I express my thanks to Zoë Simmons Hope Entomological Collections Oxford University Museum of Natural History (OUMNH) for allowing me to study types and Dmitri V. Logunov (Manchester, UK)) for assistance in visiting Oxford. I also thank Seppo Koponen (Turku, Finland) for arranging my stay in Turku and allowing us to use museum facilities. Mykola M. Kovblyuk (Simferopol, Ukraine) commented on an early draft of this manuscript. English of the final draft was corrected by Sarah Crews (San Francisco, USA).

\section{References}

Blanford W.T. 1879. Scientific results of the second Yarkand mission. Mammalia. Calcutta. $94 \mathrm{p}$.

Charitonov D.E. 1956. A survey of the family Dysderidae from the USSR fauna // Uchenye Zapiski Molotovskogo Gosudarstvennogo Universiteta. Vol.10. P.17-39 [in Russian].

Deeleman-Reinhold C.L., Deeleman P.R. 1988. Revision des Dysderinae (Araneae, Dysderidae), les especes mediterraneennes occidentales exceptees // Tijdschrift voor Entomologie. Vol.131. P.14-269.

Dunlop J.A., Penney D., Jekel D. 2017. A summary list of fossil spiders and their relatives // World Spider Catalog. Natural History Museum Bern, online at http://wsc.nmbe.ch, version 18.0, accessed on September 28, 2017

Harvey P.R., Nellist D.R., Telfer M.G. 2002. Provisional atlas of British spiders (Arachnida, Araneae). Volumes 1 \& 2. Huntington: Biological Records Centre. 406 p.

Pickard-Cambridge O. 1885. Scientific results of the second Yarkand mission. Araneida. Calcutta. 115 p. 
WSC. 2017. World Spider Catalog. Natural History Museum Bern, online at http://wsc.nmbe.ch, version 18.0, accessed on September $15,2017$.

Zhang J., Sun B., Zhang X. 1994. [Miocene insects and spiders from Shanwang, Shandong]. Beijing: Science Press. 298 p. [In Chinese with English summary]

Responsible editor: K.G. Mikhailov 